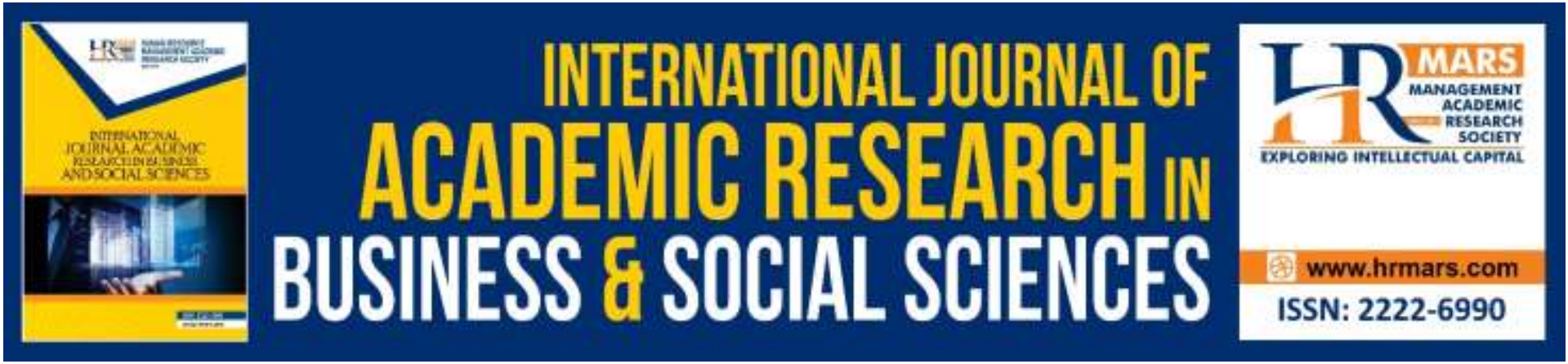

\title{
Do Corporate Governance Mechanism Influences Tax Avoidance and Firm Value?
}

\section{Agoestina Mappadang}

To Link this Article: http://dx.doi.org/10.6007/IJARBSS/v9-i10/6478

DOI: 10.6007/IJARBSS/v9-i10/6478

Received: 21 September 2019, Revised: 30 September 2019, Accepted: 01 October 2019

Published Online: 24 October 2019

In-Text Citation: (Mappadang, 2019)

To Cite this Article: Mappadang, A. (2019). Do Corporate Governance Mechanism Influences Tax Avoidance and Firm Value? International Journal of Academic Research in Business and Social Sciences, 9(10), 203217.

Copyright: (C) 2019 The Author(s)

Published by Human Resource Management Academic Research Society (www.hrmars.com)

This article is published under the Creative Commons Attribution (CC BY 4.0) license. Anyone may reproduce, distribute, translate and create derivative works of this article (for both commercial and non-commercial purposes), subject to full attribution to the original publication and authors. The full terms of this license may be seen at: http://creativecommons.org/licences/by/4.0/legalcode

\section{Vol. 9, No. 10, 2019, Pg. 203 - 217}

Full Terms \& Conditions of access and use can be found at http://hrmars.com/index.php/pages/detail/publication-ethics 


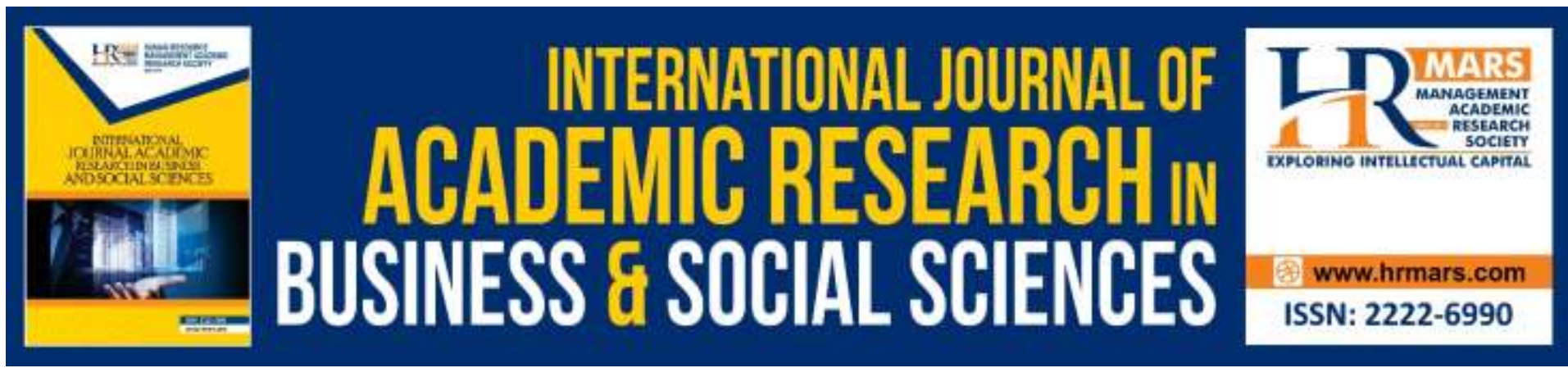

\title{
Do Corporate Governance Mechanism Influences Tax Avoidance and Firm Value?
}

\author{
Agoestina Mappadang \\ Agoestina Mappadang, Department of Accounting, Economy, Universitas Budi Luhur \\ JI. Ciledug ray, RT 10/RW 2, Petukangan Utara, Kec. Pesangrahan \\ Kota Jakarta Selatan, DKI Jakarta 12260, Indonesia \\ Email: gustinam7808@gmail.com
}

\begin{abstract}
This research is motivated by the phenomenon that exists today that many companies have poor governance so that the practice of tax avoidance is increasingly carried out. The purpose of this study is to analyze the mechanism of corporate governance as measured by independent commissioners, institutional ownership, and the board of commissioners on tax avoidance which has implications for company value. Population of this research from manufacture industries. Total sample are 87 companies and 435 objects in the period 20132017 with purposive sampling method. The results of statistical analysis using PLS-SEM. The results shown in the direct effect path that is corporate governance mechanism is a significant factor in influencing company value in a positive direction, otherwise different results shown by corporate governance mechanisms that are has a negative significance to tax avoidance and tax avoidance has a positive significance to the value of the firm. This study also examines the indirect effect (indirect effect) where the results of the analysis show the mechanism of corporate governance has a positive significance to the firm value when mediated by the variable tax avoidance. The impact of this research is that the better corporate governance as a control and supervision mechanism, the higher value of the firm, whereas a lower corporate governance mechanism makes management opportunities to do tax avoidance higher.
\end{abstract}

Keywords: Tax Avoidance, Corporate Governance Mechanism, Board of Commisioner, Independent Commissioner, Institutional Ownership, Firm Value and Tobins'q

\section{Introduction}

The owner of the company wants the value of the company to continue to increase for a long period because the higher the value of the company will also reflect the level of welfare of the owner is also higher (Fiordelisi \& Molyneux, 2010). Company value is an economic term that indicates the market value of a company and is a fundamental of the company used to measure business value and risk analysis Bayu Adi Nugroho \& Jasman, (2018). Constraints that occur in increasing the value of the company due to the internal 
company itself is how to manage the company well. Companies that have weak governance will inform from the lack of reporting on financial performance and the lack of oversight of policies and operational management. Low good corporate governance identified as one of the causes of the global financial crisis (Financial Services Authority, 2015) due to weak governance in many companies resulting in a financial scandal in the period 2008. In the ASEAN Corporate Governance Scorecard, Country Report and Assessment 2012 -2013 issued by the Asian Development Bank in collaboration with the ASEAN Capital Market Forum, stated that the results of research on 100 large companies on the Indonesia Stock Exchange obtained an average score of GCG implementation in Indonesia of $43.4 \%$. The maximum score achieved was $75.4 \%$, and the lowest score was $20.8 \%$, this indicates that the implementation of corporate governance in the majority of public companies is still weak. Weak corporate governance triggers tax avoidance actions.

In the study of Xynas (2011), it was stated that to reduce tax debts that are legal (lawful), tax avoidance is carried out. The action taken is considered to reduce tax payments so that the company's cash flow increases, but from another point of view, it will risk being able to provide high additional costs for the company. Companies that are in countries with unclear tax avoidance rules tend to do higher tax avoidance than countries where tax avoidance rules are clear (Prebble R, 2012). Tax avoidance schemes commonly used by companies according to Darussalam D, (2013): (1) transfer pricing, (2) utilization of tax heaven; (3) thin capitalization; (4) treaty shopping and (5) controlled foreign corporation. Based on the phenomenon of high levels of tax avoidance in Indonesia and government oversight and governance that is not strict, it can conclude that the opportunity for tax avoidance is even greater. Initially, research on tax avoidance focused on company characteristics that affect tax avoidance such as company operations, profitability, assets, etc. Research from (OIR \& Wilson, 2012) shows that companies with international operations lead to more opportunities to avoid tax and produce lower GAAP ETR. Besides, companies suspected of carrying out tax shelters have large book-tax differences, more inter-company activities with parent companies or overseas subsidiaries, higher effective tax rates in the previous year and less leverage. Another perspective on tax avoidance research developed in the study of Desai \& Dharmapala (2007) where first, a high tax rate system but weak with law enforcement, the tax diversion would be difficult to detect. Second, corporate governance affects the company's response to changes in tax rates. If corporate governance is weak, an increase in tax rates will result in deviations, which is to reduce state revenues. If corporate governance is strong, an increase in corporate tax rates will increase state revenues from corporate tax. Managers' actions to minimize taxation obligations are considered to be an increasingly important company activity. This is due to two things namely first, taxes can reduce at least one third of pre-tax corporate profits (Graham, Hanlon, Shevlin, \& Shroff, 2014). Second, the purpose of business and financial policy of the company is to maximize the value after tax ( Jones, Rhoades, \& Catanach, 2004). Taxes are represented as company expenses that must be managed by management (Jones et al., 2004). Companies that change inventory valuation methods for tax reasons that can make their tax payments smaller get a positive reaction from investors. Investors ignore the low book value but appreciate the tax benefits of the adoption of the company's methods.

The relationship between tax avoidance analysis and company agency theory is a review of the new and emerging empirical literature (Hanlon \& S Heitzman, 2010). Alternative 
theoretical approaches according to Chen \& Cyrus (2010) emphasize the relationship between tax avoidance and agency problems inherent in going public companies. The conflicts of interest between agents and principals as well as asymmetric information can provide opportunities for management to choose accounting methods or policies for specific purposes. Shareholders expect managers to focus on maximizing profits including reducing taxes as long as the benefits provided are greater than the costs incurred. The problem of agency and tax avoidance actions inherent in publicly owned companies has a relationship, this evidenced by the increasing between accounting earnings and tax or fiscal earnings (book-tax differences) (Desai \& Dharmapala, 2009). The increase in this difference can be caused by tax planning whose purpose will be to reduce taxable income, or the company's fiscal profit can also result in a decrease in accounting profit. Normally managers will minimize taxes without reducing company profits, or it can say that managers like to increase accounting profits without increasing fiscal profits (Hanlon \& Heitzman, 2010). The existence of corporate governance to tax avoidance is related to the agency view that affects tax avoidance actions taken by the company. In large companies, especially public companies, there is a separation of ownership and control that can lead to conflicts of interest between agents and principals. Tax avoidance actions by companies are usually directly related to shareholders. Tax avoidance structure and transactions are usually very complex and confidential so that tax authorities do not detect them. It allows managers to carry out their actions with implications for the interests of the company owner as a shareholder. Differences between company owners and management can harmonized with corporate governance oversight mechanisms and the broad quality of corporate governance mechanisms associated with better corporate performance. Research by Desai \& Dharmapala (2007) states that corporate governance affects the company's response to changes in corporate tax rates. When corporate governance is weak, an increase in tax rates results in a deviation, which is to reduce state revenues from corporate income taxes. Conversely, strong corporate governance, an increase in corporate tax rates will increase state revenues. Tax avoidance actions by companies are very complex and confidential which allows managers to be involved in various processes that endanger shareholders. Asymmetry of information between agent and principal causes a high chance of misusing managerial positions in carrying out tax avoidance methods and schemes. According to Rezaee \& Zabihollah, (2009) the principles of corporate governance applied by the company namely fairness, accountability, transparency and responsibility will provide benefits including: (1) minimizing agency costs; (2) minimizing the cost of capital by creating a positive signal to investors; (3) improve company image; (4) increase company value; (5) increase stakeholder perceptions of company performance in the future. The application of good corporate governance principles requires a corporate governance structure where companies in Indonesia generally based on two-board systems like most companies in Europe. The difference is only on the board of commissioners who are not directly in charge of the board of directors; this is following the Limited Liability Company Law no. 40 of 2007, where the board of commissioners and the board of directors are responsible to the GMS. The corporate governance mechanism is needed by the company to manage, monitor, control, and also give rewards so that it is a form of monitoring from the principal to the agent.

Based on the description above, this research focuses on the first, corporate governance mechanisms relating to company owners, namely the board of commissioners, independent commissioners, and institutional ownership will influence tax avoidance actions 
that have an impact on company value. The tax paid by the company shows the magnitude of the company's transfer to the government, and this is related to shareholders (Desai \& Dharmapala, 2007). Because the board of commissioners and shareholders are responsible and have full authority in making decisions about how to direct, control and supervise for managing resources following the company's goals so that the company's value increases. The quality of corporate governance mechanisms will be broadly related to better quality companies (Arman \& Nguyen, 2008). Second, corporate governance mechanisms related to how shareholders control managers are expected to function as a tool to give the investors' confidence that they will receive a return on the funds they invest.

\section{Hypotheses Development}

Another perspective on tax avoidance research and corporate governance mechanisms has recently been introduced into the literature by Desai \& Dharmapala (2007) who propose a situation where opportunistic managers arrange complex companies to facilitate transactions that reduce corporate taxes and divert company resources for personal use.

Base on the results of the research, it can conclude that the effect of tax avoidance on the value of the company conducted by the company has mixed results. There is a positive influence (Blaylock, Shevlin, \& Wilson, 2012) otherwise the negative influence shown by research Hanlon \& Slemrod (2009) and research from David, (2009) shows results that do not affect. Different results from several researchers indicate that the effect of firm value on tax avoidance will be differently related to the influence of earnings management Desai \& Dharmapala, (2009); Blaylock et al., (2012) and corporate governance in the company Eriel \& Angueira, (2008); Frischman, Shevlin, \& Wilson, (2008).

From the description above, the hypothesis that the authors developed in this study are:

\section{H1: Corporate Governance Mechanism Influences on Tax Avoidance}

Research conducted by Chen \& Cyrus, (2010); Jeong Bon Kim \& Yinghua Li, (2011); Khurana \& Moser, (2009), some of them conclude that there is a negative influence between the mechanism of corporate governance and tax avoidance. Several studies conducted overseas have shown that the impact of effective corporate governance mechanisms is negative on tax avoidance activities.

\section{H2: Corporate Governance Mechanism Influences on Firm Value}

The corporate governance mechanism is a system implemented by companies to regulate and control the company. Higher profit engineering is carried out in companies with lower auditor quality than companies with higher auditor quality; this also related to audit committees within the company. The company's goal is how to increase the value of the firm where the value of the company reflected in the company's stock price.

Companies that have a good corporate governance mechanism (good corporate governance) will have a more effective monitoring mechanism that will make company operations more efficient so that it will increase the value of the company (Belen, Beatriz, \& Pindado julio, 2016). 


\section{H3: Tax Avoidance Effects on Firm Value}

Tax avoidance by the company can be a positive signal for the company because this can mean the company prioritizes the interests of shareholders. Although tax minimization companies must consider the impact on financial reporting because taxation minimization strategies often use various alternative methods of accounting choices also have an impact on reducing reported earnings (Doughlas \& Shevlin, 2001).

According to Desai \& Dharmapala (2009), companies with a high level of institutional ownership have a strong positive relationship between book-tax differences and firm value. Blaylock et al., (2012) found that companies that had a large difference between book-tax earnings caused by tax avoidance were responded positively by the market as evidenced by the greater value of the earnings response coefficient. Tax avoidance by the company can interpret as a signal to investors that the company prioritizes the interests of shareholders. If the manager performs tax avoidance optimally and investors have confidence in the tax avoidance actions, there should be a positive relationship between tax avoidance and company value.

\section{H4: Corporate Governance Mechanism Influences on Firm Value with Tax Avoidance as an Intervening Variable}

The relationship between tax and corporate governance has been extensively studied, such as Desai \& Dharmapala, (2009), Hanlon \& J slemrod, (2009). Research conducted by Desai and Dharmapala (2009) reveals the relationship between incentive compensation and tax evasion is negative. This negative relationship mainly occurs in companies with a low level of governance, which is assumed to be opportunism as a dominant factor in managerial. According to Hanlon \& Slemrod, (2009) investigating how the market responds to news of corporate tax evasion, this research shows that the market responds negatively to the news. Several variations founded, where the reaction would be more positive for companies with better corporate governance. This study developed an empirical research model based on basic theoretical development and previous studies.

The empirical research model that developed illustrates the relationship between the research variables used. The empirical research model can see in Figure 2.1 below.

Picture 1

Empirical Research Model

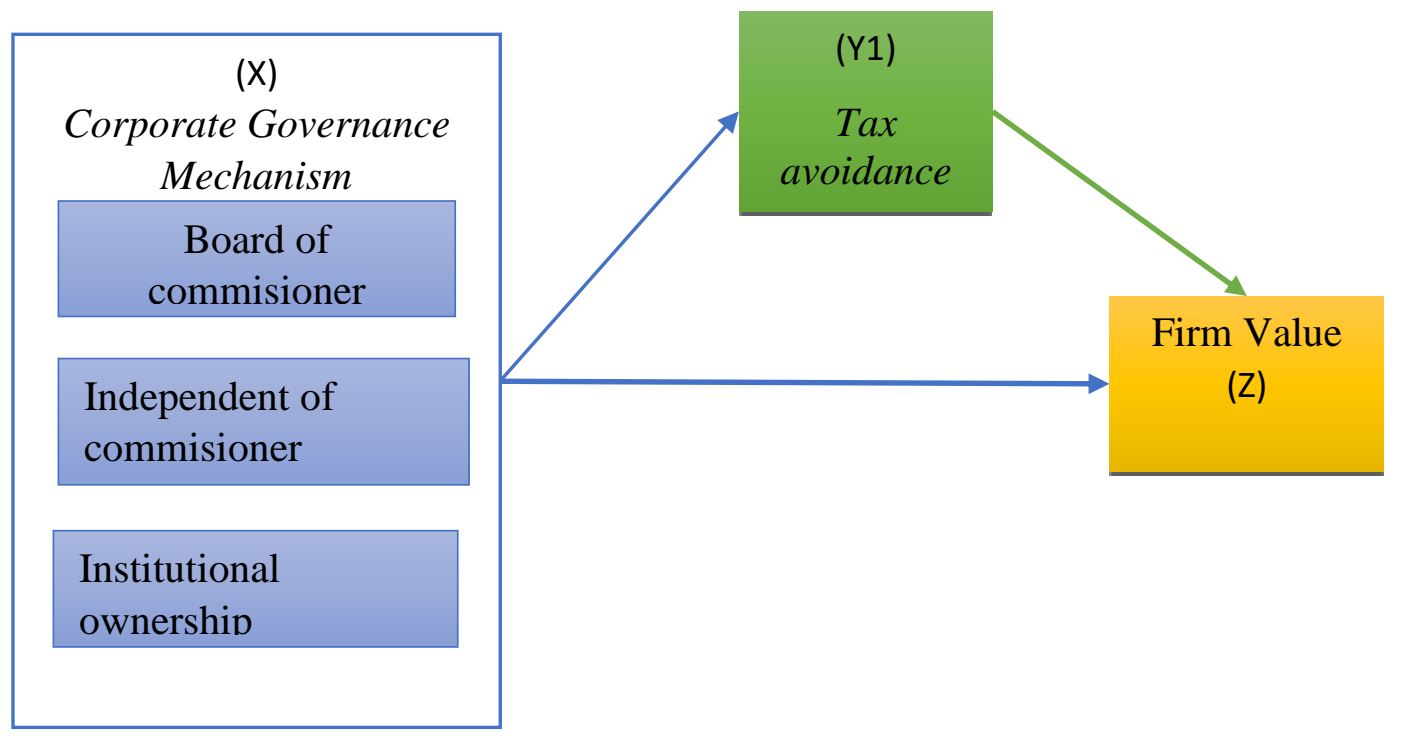


Tax avoidance is a transfer of wealth from the government to shareholders expected to be a positive signal for investors so that it can increase the company's stock price. So this study uses variables of corporate governance mechanisms, tax avoidance, and corporate value to see significant effects directly or indirectly.

\section{A Method, Data and Analysis}

This study develops a model based on variable corporate governance mechanisms on tax avoidance that have an impact on firm value. This type of research is a descriptive causality study with the purposive sampling method. This study uses a Partial Least Square (PLS) analysis tool with Smart PLS 3 Software to test hypotheses. The population of research in manufacturing industry companies listed on the Indonesia Stock Exchange in the period 20132017 with research samples obtained from the purposive sampling method was 435 companies from 87 companies. Measurement of operational variables used as follows:

Table 1. Research Variables Measurements

\begin{tabular}{|c|c|c|}
\hline Variable name & Indicators & Operational variable \\
\hline \multirow{3}{*}{$\begin{array}{l}\text { Exsogen }(\mathbf{X}) \\
\text { Corporate } \\
\text { Governance } \\
\text { Mechanism }\end{array}$} & $\begin{array}{l}\text { Commisioner } \\
\text { Board }\end{array}$ & $\begin{array}{l}\text { Number of board of commissioner owned } \\
\text { by a company }\end{array}$ \\
\hline & $\begin{array}{l}\text { Independent } \\
\text { Commisioner }\end{array}$ & $\begin{array}{l}\text { Percentage of members the board of } \\
\text { commissioner from outside company }\end{array}$ \\
\hline & $\begin{array}{l}\text { Institutional } \\
\text { Ownership }\end{array}$ & $\begin{array}{l}\text { Percentage of total shares ownership by } \\
\text { institusional investor from all of the } \\
\text { company's outstanding share capital }\end{array}$ \\
\hline $\begin{array}{l}\text { Endogen }(\mathbf{Y} 1) \\
\text { Tax avoidance }\end{array}$ & Avoidance Tax Rate & $\begin{array}{l}\text { Tax avoidance } \text { Rate }=\text { tax rate applied }- \\
\text { effective tax rate }(\text { ETR }) \\
\text { Tax rate applied is } 25 \% \\
\text { ETR }=\text { Efektif tax rate } \text { Ef }_{\text {t }}= \\
\left(\frac{\text { Total } \text { Tax Expense it }}{\text { Earning Before Tax it }}\right)\end{array}$ \\
\hline $\begin{array}{l}\text { Endogen (Z) } \\
\text { Firm value }\end{array}$ & & $\begin{array}{l}\text { Tobins'q } \\
=(\mathrm{MVE}+\mathrm{TDEBT}) / \mathrm{TA}\end{array}$ \\
\hline
\end{tabular}

Source: Develop for this research

\section{Results}

The results of testing the outer model and inner model with PLS in this study show the results in the following tables. 
Table 2. Outer Loadings

\begin{tabular}{|l|c|c|c|}
\hline & Result & Criteria & Conclusion \\
\hline ATR -> tax avoid & 1,000 & $>0,5$ & valid \\
\hline Dkom ->mechanism CG & 0,877 & $>0,5$ & valid \\
\hline Inden -> mechanism CG & 0,644 & $>0,5$ & valid \\
\hline ins-> mechanism CG & 0,928 & $>0,5$ & valid \\
\hline tobins->firmvalue & 1,000 & $>0,5$ & valid \\
\hline
\end{tabular}

The results showed that the outer loading value is valid because it is more than 0.5 so the results of this study are valid or convergent.

Table 3. Quality Criteria

\begin{tabular}{|c|c|c|c|l|l|}
\hline & AVE & $\begin{array}{c}\text { Composite } \\
\text { Reliability }\end{array}$ & $\begin{array}{c}\text { Cronbachs } \\
\text { Alpha }\end{array}$ & Criteria & \\
\hline Mechanism cg & 0.681 & 0.863 & 0.758 & $>0.6$ & reliable \\
\hline Firm value & 1.000 & 1.000 & 1.000 & $>0.6$ & reliable \\
\hline Tax Avoidance & 1.000 & 1.000 & 1.000 & $>0.6$ & reliable \\
\hline
\end{tabular}

Furthermore, the AVE value, composite reliability, and Cronbach alpha are greater than 0.6 so that the mechanism of corporate governance, tax avoidance, and company value is reliable and can continue for the next stage.

Table 4. R Square

\begin{tabular}{|c|c|}
\hline & R Square \\
\hline Firm Value & 0.705 \\
\hline Tax Avoidance & 0.489 \\
\hline
\end{tabular}

$R$ square value or determinant coefficient shows that the value of tax avoidance is 0.489 ; this shows that the value of tax avoidance can explain by the corporate governance mechanism as the independent variable of 0.489 . Furthermore, the value of the determinant coefficient of the company value of 0.489 , this shows that the value of the company can explain by corporate governance and tax avoidance as an independent variable of 0.705 , and the rest explain by other variables not explained by the model. The following is a picture of the effect of corporate governance mechanisms on company value through tax avoidance. 
INTERNATIONAL JOURNAL OF ACADEMIC RESEARCH IN BUSINESS AND SOCIAL SCIENCES Vol. 9, No. 10, October, 2019, E-ISSN: 2222-6990 @ 2019 HRMARS

Picture 2. Algorithm Method

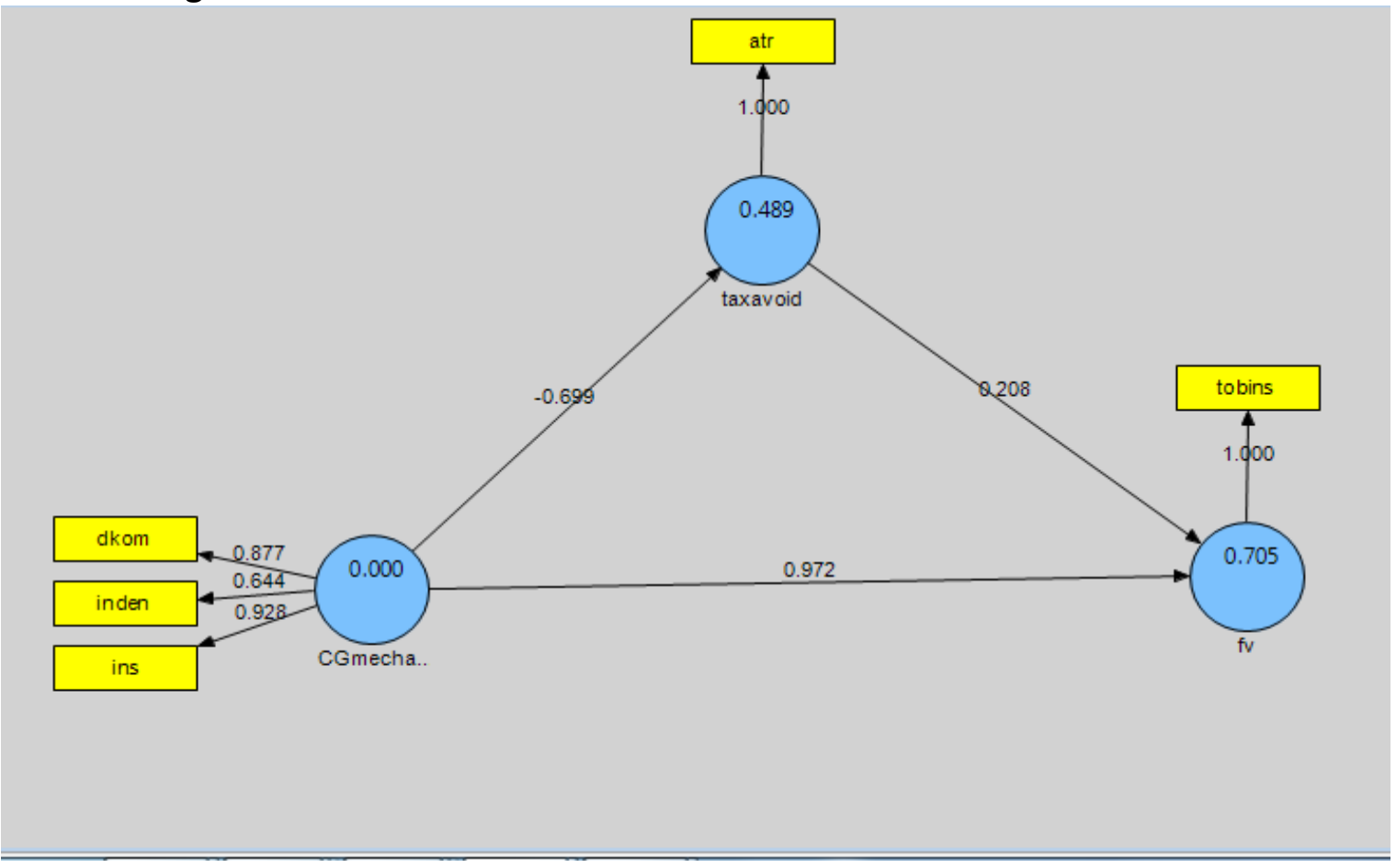

Picture 3. Bootstrapping Method

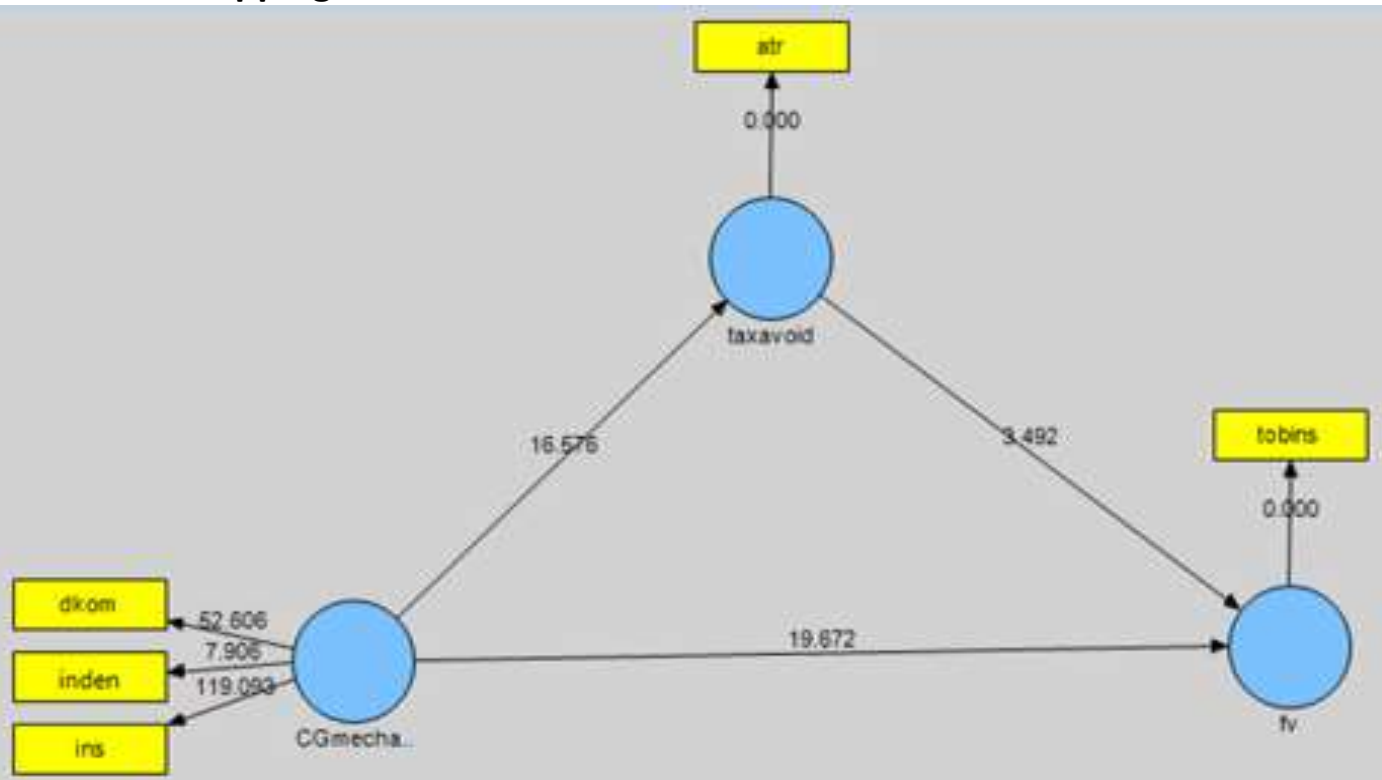


INTERNATIONAL JOURNAL OF ACADEMIC RESEARCH IN BUSINESS AND SOCIAL SCIENCES

Vol. 9, No. 10, October, 2019, E-ISSN: 2222-6990 @ 2019 HRMARS

\section{Discussion}

Hypothesis H1: Corporate governance mechanism influences on tax avoidance

Table 5. Hypothesis 1

\begin{tabular}{|l|c|c|l|}
\hline Path & $\begin{array}{l}\text { Original } \\
\text { Sample }\end{array}$ & $\mathrm{t}$-Stat & Decision \\
\hline Mechanism cg $->$ taxavoid & -0.699 & 16.576 & Accept Hypothesis \\
\hline
\end{tabular}

The first hypothesis shows that corporate governance mechanism a negative effect on tax avoidance. The results showed a negative coefficient of -0.699 with a stat of 16.576 (> 1.96) or significant at a $p$-value of less than 0.05 ,

so the first hypothesis was accepted. It means the corporate governance mechanism by the company a negative effect on tax avoidance. This study uses the proxy of institutional investors who have a majority stake in the manufacturing industry in the study period so that it has a share in every decision that automatically encourages management to comply with taxation rules and avoid tax avoidance behavior that deviates from tax assessments. Other proxies are the board of commissioners, and independent commissioners where the optimal amount and carry out their functions independently, even though large size companies with complex structures will be more oriented to compliance with legislation and high tax risk, which in the long run will result in burden cost.

Good or bad corporate governance reflect in institutional ownership, the proportion of independent board of commissioners, the board of commissioners, audit committee and audit quality Desai \& Dharmapala D, (2007). According to Minnick and Noga (2010), tax avoidance actions open opportunities for managers to be opportunistic for short-term goals, not for long-term benefits as expected by the principal. The role of corporate governance is expected to be able to control agency problems with tax avoidance actions taken by companies. The company that has good governance mechanisms will be directly proportional to the company's compliance in meeting their tax obligations (Sartori N, 2010). The results of this study agree with Armstrong, Blouin, Jagolinzer, \& Larcker, (2015); Richardson R \& Lanis, (2011), Rego Sonja OIR \& Ryan wilson, (2012) and Minnick \& noga, (2010) that corporate governance mechanisms negatively affect on tax avoidance.

\section{Hypothesis H2 : Corporate governance mechanism influences on firm value}

Table 6: Hypothesis 2

\begin{tabular}{|l|c|c|l|}
\hline Path & $\begin{array}{c}\text { Original } \\
\text { Sample }\end{array}$ & t -Stat & Decision \\
\hline Mechanism cg $>\mathbf{f v}$ & 0.972 & 19.672 & Accept Hypothesis \\
\hline
\end{tabular}

The second hypothesis shows the mechanism of corporate governance has a positive effect on firm value. The results showed a positive coefficient of 0.972 with a stat of $19.672(>1.96)$ or significant at $p$ values less than 0.05 so that the second hypothesis accepted. The results of this study mean that companies that have a mechanism of good corporate governance (good corporate governance) will have a more effective monitoring mechanism that will make 
company operations more efficient so that it will increase the value of the company. The higher the corporate governance mechanism, the higher the value of the company, which means investors react positively to good corporate governance.

This research is in line with a survey conducted by McKinsey \& co, (2002) showing that corporate governance mechanisms have become the main consideration of investors, especially in emerging markets such as Indonesia. Investors tend to avoid companies that implement bad corporate governance so that companies that have a good corporate governance mechanism (good corporate governance) will have transparency and good accountability so that it reduces information asymmetry and investors get full information on the company's performance. Financial statements have produced by companies with good governance will more positively be responded by investors and become an attraction for investors to invest in the company's shares. The effect is stock prices will be high because demand rises and this has an impact on the value of the company's higher. This study is in line with Paolo Saona \& Martin, (2016) and Teresa M Pergola, Joseph, \& Ali Jenzarli, (2006) that corporate governance mechanisms have a positive effect on company value.

\section{Hypothesis H3: Tax avoidance effects on firm value}

Table 7. Hypothesis 3

\begin{tabular}{|l|c|c|l|}
\hline Path & $\begin{array}{c}\text { Original } \\
\text { Sample }\end{array}$ & t -Stat & Decision \\
\hline taxavoid $-\mathbf{f v}$ & 0.208 & 3.492 & Accept Hypothesis \\
\hline
\end{tabular}

The third hypothesis shows that tax avoidance has a positive effect on firm value as seen from the results of data processing presented in table 8 . The resulting coefficient of 0.208 with $t$ arithmetic of $3.492(>1.96)$ From the data generated means that tax avoidance has a positive effect on firm value or investors react positively to the company's tax avoidance.

The results of this research prove that tax aggressiveness can increase or decrease the value of a company's stock. If tax aggressiveness looks like an effort to carry out tax planning and tax efficiency, then the effect is positive on firm value. However, if it looks as a noncompliance action that has a bad risk to the company's long-term sustainability, it will reduce the value of the company. If done in a non-compliance corridor, investors will react negatively. The results of this study support the research of Hanlon \& J slemrod, (2009); Desai M A \& D Dharmapala, (2009); Blaylock et al., (2012); Xudong Chen, Hu, Wang, \& Xiaofei Tang, (2013) that tax avoidance has a positive effect on firm value. 
Hyphotesis H4: Corporate Governance Mechanism Influences on Firm Value with Tax Avoidance as an Intervening Variable

Table 8. Total Effect on Path Mediation

\begin{tabular}{|l|c|c|l|}
\hline Path & $\begin{array}{c}\text { Original } \\
\text { Sample }\end{array}$ & t- Stat & Decision \\
\hline CGmechanism $->$ taxavoid $->$ fv & 0.826 & 15.422 & Accept Hypothesis \\
\hline
\end{tabular}

The results of the research presented in table 9 on the total indirect path effect, the corporate governance mechanism to the value of the company through tax avoidance is 0.826 with a stat of 15.422 , more than 1.96 or significant at $p$-value less than 0.05 . This study proves that there is an indirect effect (indirect effect) of corporate governance mechanisms on corporate value through the mediation of tax avoidance with the positive-negative effect seen from the indirect effect coefficient of 0.826 . The relationship that occurs between corporate governance mechanisms and corporate value mediated by tax avoidance is a partial mediation. In this research period that manufacturing industry companies have an average institutional ownership composition of $63 \%$ owned by insurance institutions, banks, investment companies, and other institutions so that it will encourage more optimal supervision of management performance. The number of independent commissioners in the observation period is proportional to the number of shares required by the IDX as the controlling shareholder. In table 2 the average independent commissioner is $31.8 \%$; in this case, the independent commissioner represents the interests of minority shareholders or public shareholders. With the responsibility for the public interest, the independent commissioner will fight for corporate tax compliance. This research proves that the influence of the board of commissioners, institutional ownership and independent commissioners fulfills their role as a function of monitoring so that tax avoidance actions taken by the company will not make the company's value decrease. This study strengthens the research of Xudong Chen et al., (2013) that the negative influence between tax avoidance and company value can reduced by the presence of company transparency. The other studies that support the research results of the author, namely Hanlon \& J slemrod, (2009) that in companies that have good corporate governance will lead to a relationship of tax avoidance and positive corporate value.

\section{Conclusion, Limitation and Suggestion Conclusion}

From the results of the above study, it can conclude that: first, the mechanism of corporate governance a negative effect on tax avoidance. It shows that corporate governance mechanism has a positive influence on the level of corporate tax compliance so that it will minimize tax aggressiveness. Second, the corporate governance mechanism has a positive effect on the value of the company. It shows that the corporate governance mechanism is a more effective monitoring mechanism that will make the company's operations more efficient so that it will increase the value of the company. Third, tax avoidance has a positive effect on firm value. Tax avoidance actions taken by the company can be a positive signal for the company because it prioritizes the interests of shareholders so that the value of the company will increase. Fourth, the corporate governance mechanism has a positive effect on 
company value if mediated by tax avoidance, this proves that the corporate governance mechanism, namely the board of commissioners, independent commissioners, and institutional ownership has full authority in the direction, control, and supervision so that tax avoidance actions taken by the company will not decrease the value of the company.

The contribution of this research that all company must obey in carrying out taxation rules and how to handle tax management, besides improving good corporate governance so tax penalties can be avoided and the company remains keep going concern. Tax compliance must be further improved in order to increase Indonesia's tax ratio.

\section{Limitation and Suggestions}

Based on the results of testing on the model developed in this study, there are selected sample companies for the developed model, so there are limitations of the research that become a reference for further research, namely only in the observation period. The variables studied to analyze the effect of corporate governance mechanisms only use intervening tax avoidance. For future research agenda will do first is whether the results of this study apply in different periods with different situations and regulations to prove tax avoidance affects the firm's value with abnormal returns. Secondly, developing research models by considering other variables as mediating variables or adding other variables, namely tax regulations, capital market situations or capital structures and thirdly taking observations on different industries.

\section{References}

Armstrong, Christopher, S., \& Jennifer, L. (2012). The Incentives for Tax Planning. Journal of Accounting and Economics, 53(1-2),391-411.

https://doi.org/10.1016/j.jacceco.2011.04.001

Nugroho, B. A., \& Jasman. (2018). Can managers use accruakls quality for creating investment opportunity set and increasing firm value. Binus Busniness Review, ((9(3)), 235-245. https://doi.org/10.21512/bbr.v9i3.4891

Belen, L., Beatriz, M., \& Julio, P. (2016). Corporate governance, ownership and firm value: Drivers of ownership as a good corporate governance mechanism. International Business Review, 25(6), 1333-1343. https://doi.org/10.1016/j.ibusrev.2016.04.005

Blaylock, B., Shevlin, \& Wilson, R. J. (2012). Tax avoidance, Large Positive Temporary BookTax Differences, and Earnings Persistence. The Accounting Review, 87(1), 91-120. https://doi.org/10.2308/accr-10158

Chen, K., \& Cyrus, C. Y. (2010). Internal Control vs External Manipulation: A Model of Corporate Income Tax Evasion. The RAND Journal of Economics, 36(1), 151-164. https://doi.org/10.2139/ssrn.353860

Darussalam, D. (2013). Transfer pricing: Ide, Strategi, dan Panduan dalam Perspektif Pajak International (XiV). Indonesia: Dany Darussalam Tax Center.

Desai, M., \& Dharmapala D. (2007). Taxation and Corporate Governance: An Economic Approach. Harvard Business School - Finance Unit; National Bureau of Economic Research (NBER), 24.

Desai, M. A., \& Dharmapala, D. (2009). Corporate Tax Avoidance and Firm Value. The Review of Economic and Statistic, 91(3), 537-546. https://doi.org/10.1162/rest.91.3.537 
Eriel, J. C., \& Angueira. (2008). Tax anggressiveness, tax environment changes and corporate governance. University of Florida.

Fiordelisi, \& Molyneux. (2010). The determinants of shareholder value in European banking. Journal of Banking \& Finance, Elsevier, 34((6)), 1189-1200.

https://doi.org/10.1016/j.jbankfin.2009.11.018

Frischman, Shevlin, \& Wilson. (2008). Economic consequences of increasing the conformity in accounting for uncertain tax benefits. Journal of Accounting and Economics, 46(2-3), 261-278.

https://doi.org/10.1016/j.jacceco.2008.08.002

Graham, R, J., Hanlon, \& Shevlin. (2014). Incentives for Tax Planning and Avoidance: Evidence from the Field. Journal the Accounting Review, 89(3), 991-1023.

https://doi.org/10.2308/accr-50678

Hanlon, M., \& Slemrod, J. (2009). What does tax aggressiveness signal? Evidence from stock price reactions to news about tax shelter involvement. Journal of Public Economics, 93(1-2), 126-141.

https://doi.org/10.1016/j.jpubeco.2008.09.004

Hanlon, M., \& Heitzman, S. (2010). A Review of Tax Research. Journal of Accounting and Economics, 50(2-3), 127-178.

https://doi.org/10.1016/j.jacceco.2010.09.002

Arman, H., \& Nguyen, P. (2008). Do stock prices reflect the corporate governance quality of Japanese firm. Journal of the Japanese and International Economics, 22(4), 647-662. https://doi.org/10.1016/j.jjie.2008.05.001

Kim, J. B., \& Li, Y. (2011). Corporate Tax Avoidance and Stock Price Crash Risk: Firm-Level Analysis. Journal of Finance Economics, 100(3), 639-662.

https://doi.org/10.1016/j.jfineco.2010.07.007

Khurana, I. K., \& William, J. M. (2009). Institutional Ownership and Tax Aggressiveness. Financial Accounting \& Reporting Section (FARS), (AAA2010), 43.

https://doi.org/10.2139/ssrn.1464106

McKinsey \& Co. (2002). A premium for good governance.

http://www.globalclearinghouse.org/wefhongkong/Docs/Premium\%20for\%20good\%2 Ogovernance.pdf

Minnick, \& Noga. (2010). Do corporate governance characteristics influence tax management? Journal of Corporate Finance, 16(5), 703-718.

https://doi.org/10.1016/j.jcorpfin.2010.08.005

Saona, P., \& Martin, P. (2016). Country Level Governance Variables and Ownership Concentration as Determinants of Firm Value in Latin America. International Review of Law and Economics, 47(1), 84-95.

https://doi.org/10.1016/j.irle.2016.06.004

Prebble, R. (2012). Does the use of general anti avoidance rules to combat tax avoidance breach principles of the rule of law? Saint Louis Law Journal, 55, 26. https://papers.ssrn.com/abstract $=1523043$

OIR, R. S., \& Wilson, R. (2012). Equity Risk Incentives and Corporate Tax Aggressiveness. Journal of Accounting, 50(3), 775-810.

https://doi.org/10.1111/j.1475-679X.2012.00438.x

Rezaee, \& Zabihollah. (2009). Corporate governance post-Sarbanas Oxley: reulations requirements and integrated process. CPA Journal, 79(2), 15. 
Indonesia, R. (2007). Undang-Undang no. 40 tahun 2007 tentang Perseroan Terbatas.

Richardson R, \& Lanis. (2011). The effect of board of director composition on corporate tax aggressiveness. Journal of Accounting and Public Policy, 30(1), 50-70. https://doi.org/10.1016/j.jaccpubpol.2010.09.003

Sally, M. J., Rhoades, \& Catanach. (2004). Principle of Taxation: Advanced Strategies (4th ed.). English: McGraw-Hill/Irwin.

Sartori, N. (2010). Corporate Governance Dynamics and Tax Compliance. Heinonline, (13 Int'I Trade \& Bus. L. Rev. 264).

Doughlas, S. A., \& Shevlin, T. (2001). Empirical tax research in accounting. Journal of Accounting and Economics, 31, 321-387.

Pergola, T. M.,Joseph, G. W., \& Jenzarli, A. (2006). Effects of Corporate Governance and Board Equity Ownership on Earnings Quality. University of Tampa, 56.

David, W. (2009). Do analist and investor full appreciate the implications of book tax difference for future earnings? Contemporary Accounting Research Journal, 26(4), 11751206. https://doi.org/10.1506/car.26.4.7

Chen, X., Hu, N., Wang, X., \& Tang, X. (2013). Tax avoidance and firm value. Nankai Business Review International, 5(1), 25-42.

https://doi.org/10.1108/NBRI-10-2013-0037

Xynas L. (2011). Tax Planning, Avoidance and Evasion in Australia 1970-2010: The regulatory Responses and Taxpayer Compliance. Revenue Law Journal, 20(1).

https://epublications.bond.edu.au/rlj/vol20/iss1/2 